\title{
A Psicologia Hospitalar: do corpo à narratividade: Fenomenologia no Hospital
}

Fernanda Rizzo di Lione ${ }^{1}$; Fernanda de Camargo Vianna ${ }^{2}$

\section{Resumo}

Introdução: Este trabalho se propõe a fazer uma leitura Fenomenológica Existencial da atuação do psicólogo hospitalar que trabalha com pacientes com doenças graves que ameaçam a vida e seus familiares. Método: à luz da Fenomenologia existencial abordamos os seguintes pontos: (1) a compreensão da Condição Humana, (2) Hospital e Cuidado, (3) a compreensão do adoecimento e (4) como acontece o trabalho do psicólogo. Discussão: O olhar do psicólogo volta-se para a pessoa que está doente e sofre; busca compreender o modo como esta pessoa vive, como se relaciona consigo e com os outros, seus hábitos, seus projetos, e o que a doença provoca no sentido de sua existência. A intervenção acolhe e trabalha a angústia que surge quando o paciente se depara com a própria finitude. Esse tipo de cuidado favorece um movimento de re significação e apropriação das escolhas do paciente, tendo em vista o horizonte marcado pela restrição advinda do adoecimento. Conclusão: O psicólogo hospitalar que trabalha com o referencial Fenomenológico existencial busca entender o paciente na sua singularidade em alguma ou todas as fases do ciclo da doença. Em nossa prática, os pacientes que escolhem receber suporte psicológico relatam um alívio no seu sofrimento pela possibilidade de expressar e re significar suas expectativas e experiências.

Palavras chave: Psicologia Hospitalar; Fenomenologia; Doença potencialmente fatal

Di Lione, Fernanda Rizzo; Vianna, Fernanda de Camargo. "A Psicologia Hospitalar: do corpo à narratividade: Fenomenologia no Hospital", in Anais do 2o. Congresso Internacional Sabará de Especialidades Pediátricas

\section{Referências}

\footnotetext{
${ }^{1}$ Mestre em Health Psychology pela City University, Londres, Inglaterra, 1998. e-mail: fernanda.dilione@gmail.com ${ }^{2}$ Mestre em Psicologia da Educação pela Pontifícia Universidade Católica de São Paulo, 2006. email:fecavianna@gmail.com
} 
ALVES, R. O retorno e o terno. Campinas: Papirus, 1992.

Ostra feliz não faz pérola. São Paulo: Ed. Planeta, 2008.

ARENT, H. Condição humana. São Paulo. Ed. Forense Universitária, 1999.

BOSS, M. Angústia culpa e libertação. São Paulo. Livraria Duas Cidades, 1988.

CARDINALLI, I. A doença a partir da Daseinsanalyse. Palestra proferida na Assoc. Bras. Daseinsanalyse. São Paulo, 2000.

FREIRE, E. Leitura de ser e tempo de Martin Heidegger. Curso em andamento na Associação Brasileira de Daseinsanalyse. São Paulo, 2014.

HEIDEGGER, M. El ser y tiempo. México: Fondo de Cultura Ecónomica, 1997.

POMPÉIA, J.A.; Sapienza BT. Os dois nascimentos do homem: escritos sobre terapia e educação na era da técnica. Rio de Janeiro: Via Verita Editora, 2011.

SPANOUDIS, S. A tarefa do aconselhamento e orientação a partir da daseinsanalyse. Daseinsanalyse, n.1,2,4, p.56-62, 1997.

The Health Psychology : body narrativity : Phenomenology in Hospital

\section{Summary}

Introduction : This study aims to make a Phenomenological Existential reading of hospital psychologist who works with patients with serious life-threatening illnesses and their families. Method : the use of existential phenomenology we cover the following : ( 1 ) understanding the Human Condition , ( 2 ) Hospital and Care , ( 3 ) understanding how the illness affects the patients life, and (4) how psychologists work . Discussion : The Psychologist look at the person as a whole who is suffering; seeks to understand how this person lives, how it relates to you and to others, their habits, their projects, and how the illness forms their owns sense of existence. The intervention welcomes and works with anguish that arises when the patient 
is faced with finitude. This type of arrangement allows the patient to take ownership of their owns lives, meaning and choice. Conclusion : The hospital psychologist who works with the existential phenomenological framework focuses on the uniqueness of each patient in any or all phases of the disease cycle. In our practice, patients who choose to receive psychological support reported a relief in their suffering by the possibility to express and reassess their expectations and experiences.

Keywords : Hospital Psychology ; Phenomenology ; Life-threatening illnesses 